\title{
The Austrian Biosphere Reserves in the light of changing MAB strategies
}

\author{
Günter Köck \& Arne Arnberger
}

Keywords: UNESCO, MAB Programme, world network of biosphere reserves, exit strategy

\section{Abstract}

During the past four decades UNESCO's Man and the Biosphere (MAB) Programme and its World Network of Biosphere Reserves repeatedly went through significant adaptation and modernization processes. The Seville Strategy and the Statutory Framework (UNESCO 1996), the Madrid Action Plan (UNESCO 2008) and the MAB Strategy 2015-2025 (UNESCO 2016a), followed by the Lima Action Plan 2016-2025 (UNESCO 2016b) were important steps in modernizing the biosphere reserve concept. This article describes how the Austrian MAB National Committee has responded to this ongoing revision of UNESCO standards and worked towards a solution for the different levels of quality within the Austrian biosphere reserve network.

\section{Introduction}

UNESCO's MAB Programme and its World Network of Biosphere Reserves (WNBR) play a key role in the integration of biodiversity conservation in sustainable development. For four decades, biosphere reserves (BRs) have set global standards in incorporating conservation, research, development, learning, practical knowledge and community benefits. However, this has only been possible through ongoing adaptation and fine-tuning of the MAB Programme and its biosphere reserve concept in response to the global challenges. This paper analyses the evolution of the WNBR from research-oriented sites to true model regions for sustainable development, with special attention to Austrian BRs.

The development of UNESCO's Man and the Biosphere Programme

Since 1976, when the International Coordinating Council of UNESCO's MAB Programme (MAB-ICC) designated the first $57 \mathrm{BRs}$, the MAB Programme has undergone many significant developments. The pivotal moment was in 1995, when the role of BRs was redefined at the International Conference on BRs in Seville, Spain. Crucially, it was recognized that biodiversity protection could no longer be considered separately from human needs (Price 1996, 2002; Lange 2005). Since then, regional actors have played key roles in BRs: people should be an integral element of BRs and be economically active so that they preserve their natural environment in the longer term. A decisive factor for the successful implementation of this holistic and ambitious approach is the involvement of all local interest groups in the planning and implementation of a BR. The approach aims to turn affected people into involved people and target groups into partners (Köck \& Lange 2007). This vision, plus indicators for its implementation at global, national and regional levels, was taken up in the Seville Strategy and the Statutory Framework for the World Network of Biosphere Reserves, which provided the first framework for this global network

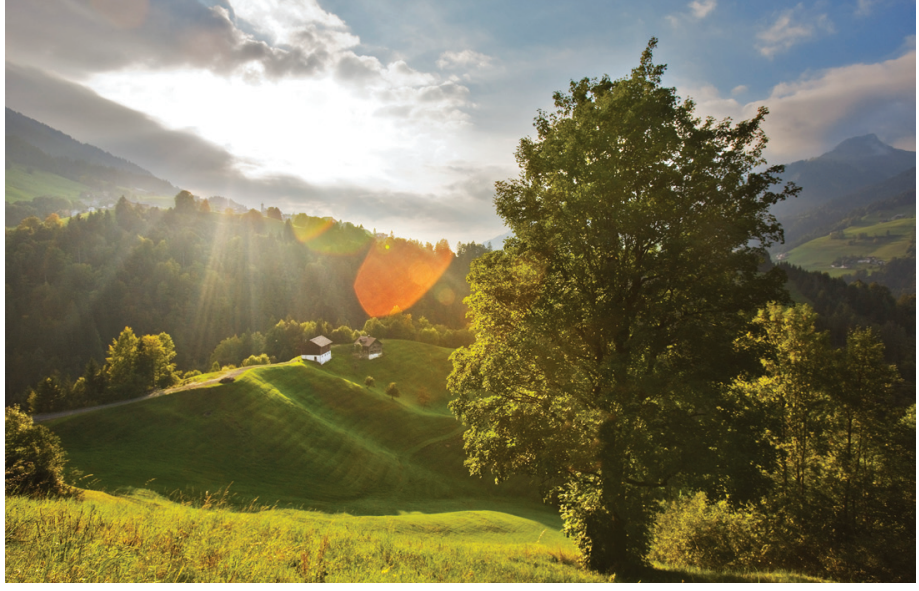

Figure 1 - BR Großes Walsertal. (C) Edition Lammerhuber, "A Connoisseur's World - The Austrian Biosphere Reserves" (Köck et al. 2009)

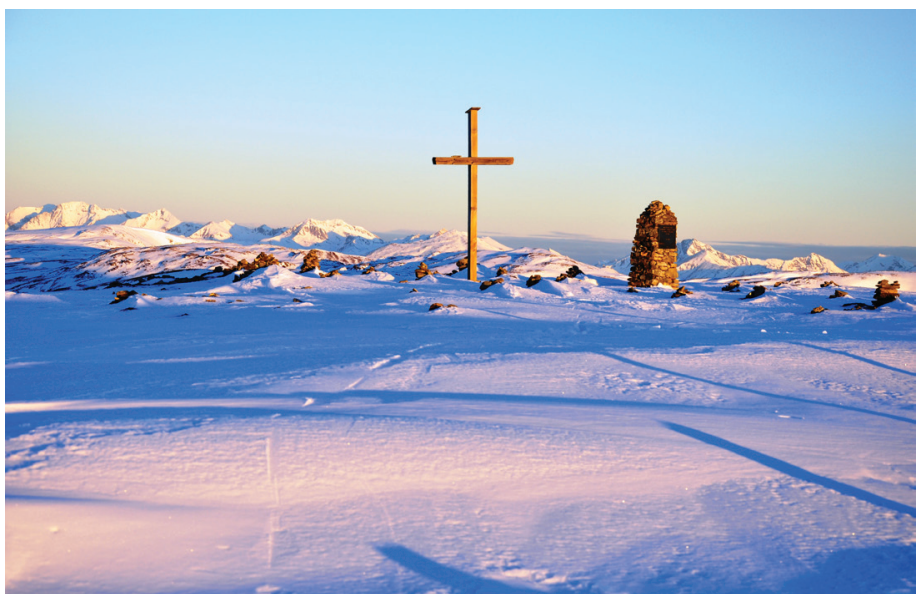

Figure 2 - BR Salz̧burger Lungan \& Kärntner Nockberge (C) Heinrich Mayer

(UNESCO 1996). This modern conservation and development concept was meant to facilitate the protection of valuable natural and cultural landscapes while also meeting the requirements of the people living in those landscapes. The Statutory Framework introduced for the first time a periodic review process to evaluate every ten years the degree to which individual sites meet the criteria for BRs specified in Article 4, e. g. appropriate zonation and existence of a management plan. 


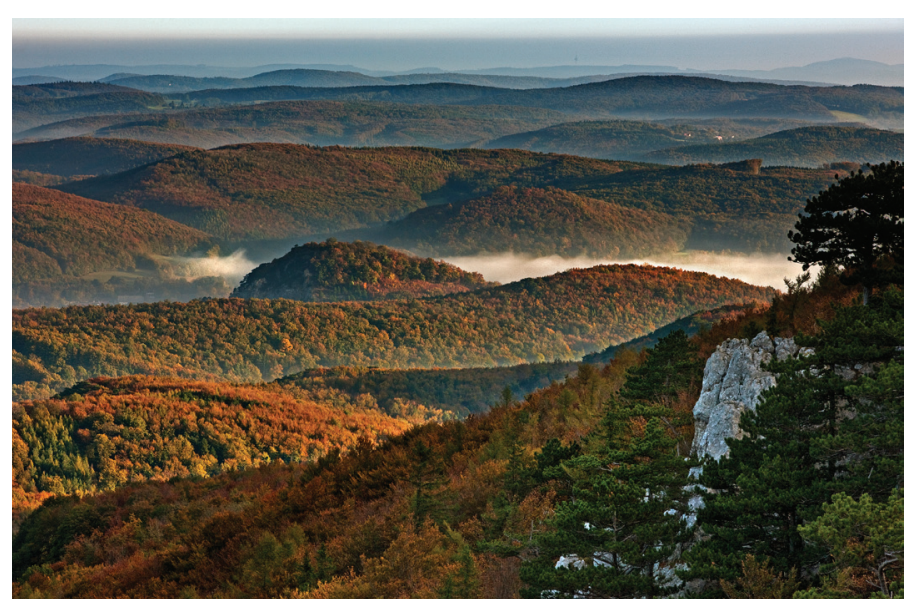

Figure 3 - BR Wienerwal. (C) Edition Lammerbuber, "111 × Biosphärenpark Wienerwald" (Schwab et al. 2010)

In 2008, at the Third World Congress of BRs in Madrid, the Seville Strategy was revisited and the $M a$ drid Action Plan (MAP) 2008-2013 (UNESCO 2008) was agreed. It aimed to prepare the WNBR for the $21^{\text {st }}$ century by promoting research, training and capacity building, especially in view of the challenges of global change (UNESCO 2008; Braun 2010). In 2013, at its $25^{\text {th }}$ session, the MAB-ICC agreed a procedure for evaluating the implementation of the MAP and for developing a future strategy for the MAB Programme and the WNBR for the period 2014-2021. The MABICC also defined a so-called exit strategy, designed as a three-stage process, to manage the periodic review process as a tool to assess, monitor and improve the quality of the WNBR (UNESCO 2013).

During its $27^{\text {th }}$ session, in 2015, the MAB-ICC adopted the $M A B$ Strategy 2015-2025, an important step in modernizing the biosphere reserve concept (UNESCO 2015). Based on this strategy, the Lima Action Plan (LAP) 2016-2025 was endorsed during the Fourth World Congress of BRs in Lima (Peru) and adopted during the $28^{\text {th }}$ session of the MAB-ICC (UNESCO 2016b). The LAP is a new ten-year action plan for the MAB Programme. It contains almost 60 concrete actions for strengthening the WNBR and its individual BRs over the next ten years and aims to promote synergies between BRs and the Sustainable Development Goals of the United Nations'2030 Agenda for Sustainable Development, adopted in Paris in 2015. With the new MAB Strategy 2015-2025, followed by the Lima Action Plan 2016-2025, UNESCO's MAB Programme and its WNBR are entering a new era of high-quality initiatives to combat the challenges facing our world.

\section{Two different levels of quality in the WNBR}

In 1976, when the WNBR was founded, classical conservation thinking prevailed. Within these firstgeneration BRs, globally representative ecosystems were protected and often seen as test sites for research projects. With the Seville Conference in 1995, the MAB
Programme underwent a significant change: The former research programme was transformed into a modern instrument for the conservation and sustainable development of regions by integrating local people and their economic activities. Research and biodiversity protection were still important, but were only two aspects of this new holistic concept (Lange 2005; Köck \& Lange 2007; Köck 2011), implemented within second-generation BRs. Even though the Seville Strategy was acknowledged internationally, there were great differences in quality of the sites within the WNBR.

Since the early years of this century, the MAB-ICC has been discussing the fact that many BRs within the WNBR do not conform to the requirements of the modern BR concept (Köck 2011). Since 2008 this discussion has become even more intense with the adoption of the MAP. This plan noted that, while nearly all BRs nominated since 1995 conformed to the modern zonation criteria mentioned in the Statutory Framework of the WNBR, a considerable number of the sites nominated between 1976 and 1995 lacked the required zonation (Price et al. 2010; UNESCO 2013). In 2008, Günter Köck undertook a survey among members of the EuroMAB Group to ascertain the possible number of first-generation BRs which could not be transformed into modern biosphere reserves. Despite a relatively low response rate of 13 countries only, he found at least 18 BRs with an unclear future (Köck 2011). Similarly, a global survey undertaken by the MAB Secretariat revealed that 18 BRs in the AsiaPacific region (or $16 \%$ of all Asia-Pacific BRs) had a single (i. e. core) zone only; in the Latin American \& Caribbean region, 14 BRs (or 13\% of the 106 Latin American BRs) had a core zone only; and in the Arab region, 3 BRs (or $20 \%$ of the current 15 Arab BRs) fell into this category (UNESCO 2011).

To address this unsatisfactory situation, the Austrian MAB National Committee (MAB-NC) suggested the definition of a new category of protected areas, so-called MAB Research Sites within the MAB Programme for first-generation BRs that cannot be converted into modern BRs, but still are of exceptional social or scientific value (Köck 2011). The proposal was first announced during the $19^{\text {th }}$ session of MABICC in 2006 (UNESCO 2006) and discussed again two years later at the $20^{\text {th }}$ session in Madrid. At the $21^{\text {st }}$ Session, in Jeju in 2009, the proposal was seconded by several countries (UNESCO 2009). At the $22^{\text {nd }}$ session, in 2010, the proposal was supported by many more countries in oral statements, as reflected in the final report of the meeting (UNESCO 2010).

In 2011 the Austrian MAB-NC funded an expert meeting at UNESCO headquarters to discuss the desirability of, and modalities for, establishing MAB Research Sites as a new category of sites different from those listed within the WNBR under the UNESCO MAB Programme (UNESCO 2011). It was emphasized that only those first-generation sites which could provide evidence of a long tradition of use as research 
Table 1 - Overview on the Austrian biosphere reserves before 2014.

\begin{tabular}{|l|r|r|r|}
\hline Biosphere reserve & Established & Generation & Size [ha] \\
\hline Gossenköllesee & 1977 & $1^{\text {st }}$ & 85 \\
\hline Gurgler Kamm & 1977 & $1^{\text {st }}$ & 1500 \\
\hline Untere Lobau & 1977 & $1^{\text {st }}$ & 1037 \\
\hline Neusiedler See & 1977 & $1^{\text {st }}$ & 25000 \\
\hline Großes Walsertal & 2000 & $2^{\text {nd }}$ & 19200 \\
\hline Wienerwald & 2005 & $2^{\text {nd }}$ & 105000 \\
\hline $\begin{array}{l}\text { Salzburger Lungau \& } \\
\text { Kärntner Nockberge }\end{array}$ & 2012 & $2^{\text {nd }}$ & 149421 \\
\hline
\end{tabular}

sites and/or of social value, thus confirming their significant value for the MAB Programme, would be eligible for the proposed new label. Two of the recommendations made by the expert meeting were that:

- those BRs designated pre-Seville with a core zone for research and protection only and which cannot meet the criteria of the Seville Strategy by 2013 should be withdrawn from the WNBR, and those first-generation BRs which cannot meet the criteria of the Seville Strategy by 2013 but which have demonstrated scientific and / or societal value for the MAB Programme and for which a Member State wishes to retain an international UNESCO designated status, may constitute a new category. These sites would not be part of the WNBR. The new category could be labelled Support/Study Sites for the MAB Programme, for example to provide scientific data/monitoring for second-generation BRs and for study themes of local, national and international interests, to focus on a specific theme, e. g. climate change, through networking with other similar Support/Study Sites and BRs, particularly those in developing countries, and / or to study sustainable development, and encourage cooperation with BRs (UNESCO 2011).

In 2012, the International Advisory Committee for BRs further reflected on the future designation of MAB Support / Study Sites, considered draft selection criteria worked out by the MAB Secretariat, and discussed the pros and cons of the creation of a new category of sites. The Advisory Committee concluded that the MAB-ICC would have to decide whether work on MAB Support/Study Sites be pursued or not, and if so, which direction it should take. In 2012, the MAB-ICC concluded that there were more cons than pros for the adoption of a new category of MAB Programme sites. The majority of MAB-ICC Member States found that BRs were already considered sites of excellence, whose value would be diminished by the adoption of the new category of MAB Support/Study Sites. Moreover, such a new category would put additional stress on the limited working capacity and delivery of the MAB Secretariat. It was also noted that a number of countries had already gone through the process of withdrawing biosphere reserves that were not in a position to comply with the criteria of the Statutory Framework (the United Kingdom had already withdrawn six sites by 2012) and that these countries had successfully managed to improve the functioning of existing BRs. With this in mind, the MAB-ICC decided to abandon work on the new category of MAB Support / Study Sites (UNESCO 2012).

As noted above, in 2013, the MAB-ICC adopted a three-stage exit strategy to deal with first-generation BRs (UNESCO 2013). This was a decisive step in ensuring quality control within the global BR network, which will in the medium term only include modern, second-generation BRs.

Development of the Austrian BRs in the light of changing MAB strategies

Austria, one of the first nations involved in the MAB Programme, established its MAB-NC in 1973, just two years after the start of the programme (Köck \& Grabherr 2014). The first Austrian BRs were established in 1977: Gossenköllesee and Gurgler Kamm in Tyrol, Untere Lobau in Vienna and Neusiedler See in Burgenland. At that time the initiative for the selection of these areas came from scientists. For many years, therefore, it was mainly basic research that went on in these areas. In 2000 the first second-generation BR was established in Großes Walsertal (Vorarlberg), followed in 2005 by the Wienerwald BR (Vienna and Lower Austria) and in 2012 by Salzburger Lungau and Kärntner Nockberge BR (Salzburg and Carinthia) as a further model region for sustainable development, a term which would never fit the four Austrian pre-Seville sites (Table 1).

In 2006, the Austrian MAB-NC concluded that, in Austria's first-generation BRs UNESCO's international criteria had been implemented insufficiently and

Table 2 - First-generation BRs and their compliance with UNESCO and national criteria.

\begin{tabular}{|l|r|r|r|r|}
\hline UNESCO Seville and national criteria & $\begin{array}{l}\text { Gossen- } \\
\text { köllesee }\end{array}$ & $\begin{array}{l}\text { Gurgler } \\
\text { Kamm }\end{array}$ & $\begin{array}{l}\text { Untere } \\
\text { Lobau }\end{array}$ & $\begin{array}{l}\text { Neusiedler } \\
\text { See }\end{array}$ \\
\hline Zonation & no & no & no & no \\
\hline Population within BR boundaries & no & no & no & no \\
\hline BR management & yes & yes & yes & yes \\
\hline Scientific value & marginal & yes & yes & yes \\
\hline Cultural and societal value & no & no & no & yes \\
\hline Area size (> 15000 ha) & no & no & no & no \\
\hline Core zone $>5 \%$ of area \& buffer zone including core zone $>20 \%$ & no & no & no & no \\
\hline Legal basis & & &
\end{tabular}


they definitely did not live up to the term model region for sustainable development (see below). Consequently, the MAB-NC implemented National Criteria for BRs in Austria (updated in 2016), allowing a five-year transition period for the first-generation sites (Austrian MAB-NC 2006, 2016; Köck 2011). At the end of that period, if these sites did not adequately meet the criteria, they would be withdrawn from the WNBR. At the same time, the National Committee started redesign initiatives (e.g. in the BRs Neusiedler See and Gurgler Kamm) to transform its first-generation sites into second-generation BRs (Wrbka et al. 2009, 2012). However, this process turned out to be lengthy and difficult, as described in detail by Köck (2011) for Gossenköllesee BR, at that time the smallest biosphere reserve in the world, yet of high scientific value. For the Austrian MAB-NC it was obvious that, owing to their long history of research activities, many of the Austrian BRs were particularly valuable research sites providing important long-term data for environmental monitoring. However, these sites did not fulfil the criteria of a modern BR, as they were mostly too small and lacked a legal protection status and comprehensive zonation. Also, there were very few, if any, people living within or close to the boundaries of the biosphere reserves, there was no separate BR management and a lack of official government funding. For geographical and political reasons, the chances of transforming these sites into modern BRs were small. Consequently, the only option for the Austrian MAB-NC would be to withdraw the BRs from the WNBR. However, withdrawal of the BR designation was at that time not a satisfactory option for every site. The Gossenköllesee, for example, is very close to a skiing area and has been threatened by its extension for 20 years. In the past, the UNESCO label had helped to protect the lake from being included in the skiing area. If it lost its designation it would most likely be impacted by the construction of new ski facilities and thus be lost to the research community.

In the discussions with stakeholders, many arguments for and against rezoning were raised. From the committee's point of view, the main concerns for the two Tyrolean BRs, for instance, were that the local stakeholders suspected that rezoning and enlargement of the BRs would interfere with or even block the economic strategies for the areas, e. g. the construction of roads and houses, the enlargement of ski resorts, the establishment of new ski pistes or the expansion of agricultural area. In these areas important stakeholders often have dual roles, as both mayor and owner of tourist facilities or large agricultural areas. When such very influential stakeholders oppose a $\mathrm{BR}$, it is very difficult to proceed with its enlargement. At the same time, and for political reasons, it is also difficult to receive backing from the provincial government.

Unfortunately the efforts of the Austrian MAB$\mathrm{NC}$ towards rezoning and expanding the four firstgeneration sites were not rewarded. Following all re- views and consultations with many stakeholders and local authorities, it became clear that the four BRs did not meet the current criteria for BR accreditation. Therefore, the Austrian MAB-NC recommended the removal of its first-generation BRs from the WNBR. Although these areas lost their UNESCO label, they are still under nature protection (see below).

Since 2014 Austria has reduced the number of its BRs from seven to three. However, the quality of the remaining BRs is exceptional. While the Austrian MAB-NC - which has always been committed to working towards a solution for the first-generation BRs (see Research Sites) - fully supports the exit strategy adopted by the MAB-ICC in 2013, support on a global level seems to be very limited. In April 2016, UNESCO listed only 18 (!) withdrawals of BRs by seven countries since 1997, including the four Austrian ones and eight from the UK (UNESCO 2016c). If UNESCO wants to further develop and increase the quality of the WNBR, a consistent enforcement of the Statutory Framework and the LAP plus the exit strategy is necessary to preserve the credibility of the outstanding MAB Programme.

Description of the four former Austrian BRs and actions taken by the National Committee

\section{Gossenköllesee}

Description: Gossenköllesee, a high-mountain lake situated at $2417 \mathrm{~m}$. a. s. 1. in the Stubai Alps, has a lake surface area of $1.6 \mathrm{ha}$. The BR consisted only of the lake and its catchment area and, with a size of only 85 hectares, was the world's smallest BR at the time. The only form of land use in the area is grazing by sheep. No humans live in the catchment area of Gossenköllesee. The nearest village is Kühtai, one of the best-known ski resorts in Tyrol. To date the Gossenköllesee BR is reserved exclusively for research. Since 1997 research activities have focused on studying the effects of global ecological change on catchment areas for high-alpine waters (Psenner 2009). The well-equipped Limnological Research Station of the University of Innsbruck, which has collected climate data for more than 30 years, turned the BR into an important centre of high-mountain research in Europe. Gossenköllesee is the only high-mountain lake in Europe with a well-endowed research station where equipment-intensive measurements can be taken. Thus, the BR was the place of choice for participation in the research cooperation project GLOCHAMORE, jointly run by the UNESCO MAB Programme and the Mountain Research Initiative.

Actions taken: For geographical and political reasons the overall chances of transforming the area into a modern BR were small. So the MAB-NC and scientists from the University of Innsbruck started an initiative encouraging the provincial authorities to continue protecting the site as a special protection area under provincial law. A letter about the critical 
status of the BR was sent by the Deputy Rector of the University of Innsbruck to the provincial government in February 2013, followed by a discussion in the Advisory Committee for Nature Conservation of the Province of Tyrol concerning a proposal to create an alternative protection status under provincial law. In December 2013 the MAB-NC informed the provincial government in a letter about the critical status of the BR as well as the exit strategy and its consequences. During a discussion with government representatives in January 2014 it became clear that stakeholders from the communities around the BR felt they would not benefit from the extension and re-zonation of the BR area. Provincial authorities moreover concluded that they did not have the capacity to pursue further work towards an application to UNESCO's MAB Programme for a more extensive $\mathrm{BR}$ along the criteria of Article 4 of the Statutory Framework of the WNBR. The provincial authorities confirmed this in writing in their letter dated February 2014. Following the decision of the Austrian MAB-NC, the site was removed from the WNBR during the $26^{\text {th }}$ session of the MABICC in June 2014.

\section{Gurgler Kamm}

Description: Gurgler Kamm BR, situated in the south-eastern part of the Ötztal Alps at elevations from 1900 to 3400 m. a. s. 1., covered an area of 1500 ha bordering on Italy in the south-east. A stone pine forest of some 20 hectares is one of the botanical attractions of the area. In Obergurgl some of the specimen trees are over 400 years old. For centuries this forest was protected by the local population and in 1963 it was designated a natural monument.

No humans live in the area of the Gurgler Kamm. The nearest village is Obergurgl, a well-known ski-resort, inhabited by around 400 people and part of the municipality of Sölden (one of the most prominent tourism destinations in Austria with more than 2 million overnight stays a year).

$90 \%$ of the BR is located within the refugia zone (Ruhegebiet) of the Ötztal Alps, which was established 1981. In 2006, the area was included in the Naturpark Ötztal, the third-largest nature park in Austria.

The path leading over the cols of the Upper Ötztal valley was in use more than 6000 years ago, making this one of the oldest routes between the Northern and the Southern Alps. After the Second World War, tourism was discovered as an important economic factor for the region and triggered a building boom: hotels, ski pistes and lifts left their mark on the landscape. Nowadays the Ötztal is one of the most intensively touristy regions of the entire Alps. In 1991, the discovery of Ötzi, the ice man of Similaun, focused the attention of the scientific world on the history of this ancient natural and cultural environment.

The University of Innsbruck has carried out research on the Gurgler Kamm for decades, setting up an Alpine Research Station in Obergurgl in 1951.
It was renovated in 2004 and is now run as the new and very well equipped University Centre, a site for research, conferences and sports. For the MAB sector one of the most significant projects was the MAB metaproject Obergurgl, launched in 1973, and dedicated to studying the ecosystem in the municipality of Obergurgl in all its ecologic and socio-economic components. Obergurgl should stand for a limited miniature cosmos and reflect the basic limitations of the total biosphere. The most significant outcome was a computer model which included a wide range of ecologic and socio-demographic framework conditions, from wildlife biology to demographics, and was internationally recognized as a pioneering feat of applied computer-aided system analysis, way ahead of its time (Köck et al. 2014). Numerous research projects were financed by the Austrian MAB-NC.

Actions taken: In December 2007, the MAB-NC informed the Tyrolean government about the critical status of the BR. In 2009, the MAB Committee and scientists from the University of Innsbruck started an initiative encouraging the local and provincial authorities to re-zonate and enlarge the site, e. g. in cooperation with the adjacent village of Vent and / or as cross-border site with Italy - South Tyrol (Südtirol / Alto Adige), Autonome Provinz Bozen Südtirol (Provincia Autonoma di Bolzano Alto Adige). In 2009, the management of Naturpark Ötztal, responsible for the BR Gurgler Kamm, launched a feasibility study for a re-zonation of the BR. In January 2010, the results of the feasibility study, including four re-zonation scenarios, were presented in a workshop (Lange 2010). In September 2010, during a workshop aimed at discussing the re-zonation scenarios, representatives from South Tyrolean villages adjacent to the Austrian border expressed their interest in a cross-border BR. In December 2010 the issue was discussed with representatives of the Department for Environment of the government of South Tyrol who proposed an INTERREG project to deal with this issue. In January 2011, a working group was established to design a joint INTERREG project proposal with South Tyrol. In February 2011 the working group received (neutral, non-negative) feedback from the provincial authorities on financial support from the Tyrolean government for a joint INTERREG project. However, after intense discussions over a period of several months, the scientists and stakeholders could not agree on an effective proposal and there seemed a lack of support from the local stakeholders in the valley for a re-zonation of the BR. Work on a joint proposal was therefore stopped in early 2012.

In December 2012 and December 2013, the MABNC informed the provincial government about the critical status of the BR as well as the exit strategy and its consequences. During a discussion with government representatives in January 2014 it turned out that stakeholders from the communities around the BR felt that they would not benefit from the extension and re-zonation of the BR area. The provincial 
authorities also claimed that they did not have the capacity to pursue further work towards an application to UNESCO's MAB Programme for a more extensive BR along the criteria of Article 4 of the Statutory Framework of the WNBR. They confirmed this in writing in February 2014. Following the decision of the Austrian MAB-NC the site was removed from the WNBR during $26^{\text {th }}$ session of the MAB-ICC in June 2014.

\section{Untere Lobau}

Description: The area of the Untere Lobau, covering an area of $1037 \mathrm{ha}$, is situated in the continental, sub-Pannonian wetlands on the left bank of the Danube River east of Vienna. The Lobau and the Danube riverine wetlands to the east of it are the last complete riverine wetlands of this magnitude in the whole of Central Europe. They are habitat and retreat for numerous endangered plant and animal species.

No humans live in the area of the Untere Lobau. However, it is a popular recreation area for the population of the region, and the proximity to the large city of Vienna with its 1.8 Mio inhabitants puts the area under pressure. In 1996 the area became part of Donau-Auen National Park (NP) and is also protected under Ramsar and Natura 2000 conventions.

The establishment of Untere Lobau BR was an important milestone for nature protection in this stretch of the Danube River. For many years the special ecological importance of the area triggered numerous research projects on water fauna, bird life, forest and water vegetation, as well as visitor management. The research was oriented on a research concept introduced in 1998 and approved by the NP. Numerous research projects were financed by the Austrian MAB-NC.

Actions taken: Discussions between the MAB-NC and those responsible for the BRs about re-zonation strategies began soon after the implementation of the Criteria Catalogue for Austrian BRs in 2006. In December 2012 the MAB-NC informed the Government of the City of Vienna about the critical status of the $\mathrm{BR}$, as well as the exit strategy and its consequences, followed by a discussion with members of the provincial government about re-zonation options in January 2013. A second information letter to the provincial government was sent in June 2014, followed by a comprehensive discussion of all aspects and obstacles with members of the provincial authorities. It became clear that the stakeholders clearly prioritized the nature protection provided through the existing IUCN Category II NP.

Therefore the City of Vienna abandoned the transition from a first-generation to a second-generation BR along the criteria of Article 4 of the Statutory Framework of the WNBR, confirming this in writing in November 2015. Following the decision of the Austrian MAB-NC the site was removed from the WNBR during the $28^{\text {th }}$ session of the MAB-ICC in March 2016.

\section{Neusiedler See}

Description: The region around Neusiedler See, a large lake situated in the easternmost part of Austria on the border with Hungary, is a transitional area between the Alps and the Little Hungarian Plain, the westernmost steppe landscape in Europe. From a biological point of view this area offers a variety of habitats: Alpine, Pannonic, Asian, Mediterranean, and Nordic influences enrich the extraordinary diversity. The BR, covering an area of 25000 ha, consisted only of the lake area on the Austria side with its reed belt. In 1992 one part of the BR became the core zone of Neusiedler See - Seewinkel NP, which is also Austria's largest Ramsar site. The appearance of this highly diverse habitat (e.g. lake, reed belt, treeless saline soils, salt ponds, pastures, wet meadows) with its fascinating diversity of plant and animal species is partly the result of human intervention. During the bird migration seasons more than 150 different species of birds stop in the area, making it a hotspot for bird enthusiasts from all over the world. In addition, 1500 butterfly species and more than 40 species of mammal live in the area and more than 20 species of fish in the lake.

No humans live in the BR area. Approximately 35000 people live in the region around the lake. Tourism and viticulture are the most important economic factors in the region.

In the early 1970s, extensive research was undertaken in the reed belt and in the lake itself within the framework of UNESCO's International Biological Programme. In the 1980 s, one of the first MAB projects was carried out in the region. Research topics of the research station Biological Station Neusiedler See in Illmitz, built in 1971, were limnologic studies, fish biological investigations, monitoring of pastures, bird species monitoring and long-term scientific research. Numerous research projects were also funded by the Austrian MAB-NC.

Actions taken: Discussions between the MAB-NC and those responsible for the BRs about re-zonation strategies began soon after the implementation of the Criteria Catalogue for Austrian BRs in 2006. Two larger re-zonation projects were financed by the $\mathrm{MAB}$ Committee to facilitate the transfer of this first-generation site into a modern Seville-style BR.

The provincial authorities were informed about impending changes in December 2012, June 2014 and October 2015, but did not respond. In October 2015 the National Committee contacted the relevant authorities for the adjacent Hungarian second-generation Fertö BR to inform them about the situation in Austria and to ask for their feedback. Both sides stated that a delisting of the Austrian BRs would not affect the status of core zone of the Hungarian BR because the area would keep its protection status as core zone of the NP. After comprehensive discussions the MAB-NC was convinced that the stakeholders seemed to prioritize the labels NP and World Heritage Site for their region. The Committee interpreted this as 
the stakeholders not wanting to pursue the transition from a first-generation site to a second-generation BR along the criteria of Article 4 of the Statutory Framework of the WNBR. The site was removed from the WNBR during the $28^{\text {th }}$ session of the MAB-ICC in March 2016.

\section{Acknowledgements}

We would like to thank Martin Price (Centre for Mountain Studies, Perth College, University of the Highlands and Islands) for a critical reading of the manuscript and his helpful comments.

\section{References}

Austrian MAB-NC 2006. National Criteria for Biosphere Reserves in Austria. In: Österreichische Akademie der Wissenschaften - MAB-Nationalkomitee (ed.), Erhalt der biologischen und kulturellen Vielfalt. Modelle für nachbaltige Entwicklungsstrategien im 21. Jahrbundert. Orte der Forschung, Bildung und Umweltbeobachtung. Vienna. Available at: http://epub.oeaw. ac.at/0xc1aa500d_0x0011e796.

Austrian MAB-NC 2016. Criteria for Biosphere Reserves in Austria.

Braun, V. 2010. Research concepts in protected areas in the Alps. eco.mont 2(2): 55-60.

Köck, G. 2010. Mountain and global change research programmes in Austria In: Borsdorf, A., G. Grabherr, K. Heinrich, B. Scott \& J. Stötter (eds.), Challenges for Mountain Regions - Tackling Complexity: 16-19.

Köck, G. 2011. A new Label for Biosphere Reserves with a Long Research Tradition? The Case Study of the Gossenköllesee BR, Austria. In: Austrian MAB Committee (ed.), Biosphere Reserves in the Mountains of the World - Excellence in the Clouds? 60-63.

Köck, G. \& G. Grabherr 2014. 40 years of the UNESCO Man and the Biosphere Programme in Austria a success story of ecologic basic research evolving into a flagship of transdisciplinarity. eco.mont 6(1): 57-62.

Köck, G., G. Koch \& C. Diry 2009. The UNESCO Biosphere Reserve „Biosphärenpark Wienerwald“ (Vienna Woods) - a Long History of Conservation. eco.mont 1(1): 51-56.

Köck, G., L. Lammerhuber \& M. Umhack 2011. Vielfalt genießen - Das Kochbuch der österreichischen Biosphärenparks (A Connoisseur's World - The Austrian Biosphere Reserves).

Köck, G. \& S. Lange 2007. UNESCO biosphere parks in Austria - model regions for sustainable development. Perspektiven 7: 14-18.

Lange, S. 2005. Inspired by diversity. Available at: http://epub.oeaw.ac.at/3596-3inhalt.

Lange, S. 2010. BSP Gurgler Kamm - Wohin? Mögliche Erweiterungsszenarien. Präsentation für den MAB-Worskhop in Niederthai, Jänner 2010. [In German]
Price, M. 1996. People in biosphere reserves: an evolving concept. Society and Natural Resources 9: 645654.

Price, M. 2002. The periodic review of biosphere reserves: a mechanism to foster sites of excellence for conservation and sustainable development. Environmental Science \& Policy 5: 13-18.

Price, M.F., J.J. Park \& M. Boumrane 2010. Reporting progress on internationally designated sites: The periodic review of biosphere reserves. Environmental Science \& Policy 13 (6): 549-557.

Psenner, R. 2009. Long-term research in the Biosphere Reserve Gossenköllesee. In: Köck, G., L. Lammerhuber \& W. Piller (eds.), Planet Austria - Stein, Wasser, Leben: 272-279 Available at: http://www. planet-austria.at/0xc1aa500e_0x002205ac.pdf

Schwab, A., G. Koch \& L. Lammerhuber 2010. Biosphärenpark Wienerwald. [In German]

UNESCO 1996. The Seville Strategy for Biosphere Reserves and the Statutory Framework of the World Network of Biosphere Reserves. UNESCO, Paris.

UNESCO 2008. Madrid Action Plan for Biosphere Reserves (2008-2013). Available at: http://unesdoc. unesco.org/images/0016/001633/163301e.pdf (accessed 15/04/2016).

UNESCO (2009). Final report of the $21^{\text {st }}$ Session of the International Coordinating Council of the Man and the Biosphere (MAB) Programme. Available at: http://www.unesco.org/mab/doc/icc/2009/e_ finalRep.pdf (accessed 15/04/2016).

UNESCO 2010. Final report of the $22^{\text {nd }}$ Session of the International Coordinating Council of the Man and the Biosphere (MAB) Programme. Available at: http://www.unesco.org/mab/doc/icc/2010/e_ finalRep_may.pdf (accessed 15/04/2016)

UNESCO 2011. Final Report: Expert Meeting on "MAB Research Sites". 21 February 2011, UNESCO Headquarters, Paris.

UNESCO 2012. Final report of the $24^{\text {th }}$ Session of the International Coordinating Council of the Man and the Biosphere (MAB) Programme. Available at: http://www.unesco.org/new/fileadmin/ MULTIMEDIA/HQ/SC/pdf/SC-12-CONF-224. Corr_en.pdf (accessed 15/04/2016)

UNESCO 2013. Final report of the $25^{\text {th }}$ Session of the International Coordinating Council of the Man and the Biosphere (MAB) Programme. Available at: http:/ / www.unesco.org/new/fileadmin/MULTIMEDIA/ HQ/SC/pdf/SC-13-CONF-225-11_Final_Report_ en.pdf (accessed 15/04/2016)

UNESCO 2014. Final report of the $26^{\text {th }}$ Session of the International Coordinating Council of the Man and the Biosphere (MAB) Programme. Available at: http://www.unesco.org/new/fileadmin/ MULTIMEDIA/HQ/SC/pdf/SC14-CONF-22615-MAB-ICC_Final_Report_en_8-7-2014-v2.pdf (accessed 15/04/2016)

UNESCO 2015. Final report of the $27^{\text {th }}$ Session of the International Coordinating Council of the Man and 
the Biosphere (MAB) Programme. Available at: http:/ / www.unesco.org/new/fileadmin/MULTIMEDIA/ HQ/SC/pdf/FINAL_REPORT_27_MAB-ICC_env2.pdf (accessed 15/04/2016)

UNESCO 2016a. Final report of the $28^{\text {th }}$ Session of the International Coordinating Council of the Man and the Biosphere (MAB) Programme.

UNESCO 2016b. Lima Action Plan for for UNESCO's Man and the Biosphere (MAB) Programme and its World Network of Biosphere Reserves (20162025). UNESCO, Paris. Available at: http://www. unesco.org/new/fileadmin/MULTIMEDIA/HQ/ SC/pdf/Lima_Action_Plan_en_final.pdf (accessed 15/04/2016)

UNESCO 2016c. Biosphere reserves withdrawn from the World Network of Biosphere Reserves. Available at: http://www.unesco.org/new/en/ natural-sciences/environment/ecological-sciences/ biosphere-reserves/withdrawal-of-biospherereserves/ (accessed 28/06/2016)

Wrbka, T., M. Prinz, C. Renetzeder, A. StockerKiss, C. Brandenburg \& K. Ziener 2009. Redesigning the Biosphere Reserve Neusiedler See. Vienna. doi: 10.1553/ rbrns

Wrbka, T., C. Hainz-Renetzeder, M. Kuttner, A. Hermann, C. Brandenburg, K. Ziener, B. Allex, U. Liebl, C. Czachs, É. Konkoly Gyuró, Á. Tirászi, P. Balázs \& V. Bacsárdi 2012. Biodiversity and Ecosystem Services as scientific foundation for the sustainable implementation of the Redesigned Biosphere Reserve "Neusiedler See". Vienna. doi: 10.1553/bioserv-neusiedler-see

\section{Authors}

\section{Günter Köck}

is Secretary-General of the Austrian MAB National Committee, former Vice-Chair of the UNESCO MAB Programme, and the Austrian delegate to the European Alliance of Global Change Research Committees, member of the Scientific Board of Hohe Tauern National Park, as well as one of the Austrian delegates to the International Scientific Committee for Alpine Research. In 2009 he became co-editor of eco. mont.

\section{Arne Arnberger}

Born 1968. Associate professor of landscape planning. Researches and teaches at the Institute of Landscape Development, Recreation and Conservation Planning at the BOKU. Research topics: outdoor recreation in protected areas, forests and green spaces in ru al and urban settings, landscape aesthetics, social and ecological carrying capacities, visitor monitoring and management, simulation modelling of visitors and ecotourism. E-mail: arne.arnberger@boku.ac.at 